\title{
AN INTERNATIONAL DYNAMIC ASSET PRICING MODEL
}

\author{
Robert J. Hodrick \\ David Tat-Chee $\mathrm{Ng}$ \\ Paul Sengmueller
}

Working Paper 7157

http://www.nber.org/papers/w7157

\section{NATIONAL BUREAU OF ECONOMIC RESEARCH \\ 1050 Massachusetts Avenue \\ Cambridge, MA 02138 \\ June 1999}

This paper was written for a conference honoring the economic contributions of Robert P. Flood, which was held on January 15-16, 1999 at the International Monetary Fund. We thank the participants at the conference, especially Marjorie Flavin, Paul Kaplan, and Louis Scott, for their comments. We also thank Geert Bekaert, John Campbell, Ken Froot, and Owen Lamont for their comments, as well as the participants in seminars at Columbia University, Georgetown University, Stanford University, the NBER International Finance Group, and the New York Federal Reserve Bank. We are very grateful that Owen Lamont and Kenneth French each provided us with part of the data. All opinions expressed are those of the authors and not those of the National Bureau of Economic Research.

(C) 1999 by Robert J. Hodrick, David Tat-Chee Ng, and Paul Sengmueller. All rights reserved. Short sections of text, not to exceed two paragraphs, may be quoted without explicit permission provided that full credit, including $(\mathbb{C}$ notice, is given to the source. 
An International Dynamic Asset Pricing Model

Robert J. Hodrick, David Tat-Chee Ng, and Paul Sengmueller

NBER Working Paper No. 7157

June 1999

JEL No. G0, F3

\begin{abstract}
We examine the ability of a dynamic asset-pricing model to explain the returns on G7country stock market indices. We extend Campbell's (1996) asset-pricing model to investigate international equity returns. We also utilize and evaluate recent evidence on the predictability of stock returns. We find some evidence for the role of hedging demands in explaining stock returns and compare the predictions of the dynamic model to those from the static CAPM. Both models fail in their predictions of average returns on portfolios of high book-to-market stocks across countries.
\end{abstract}

Robert J. Hodrick

Graduate School of Business

Columbia University

3022 Broadway

New York, NY 10027

and NBER

rh169@columbia.edu

Paul Sengmueller

Department of Economics

Columbia University

New York, NY 10027

pfs11@columbia.edu
David Tat-Chee $\mathrm{Ng}$

Department of Economics

Columbia University

New York, NY 10027

tdn@columbia.edu 


\section{Introduction}

The starting point of this paper is the observation of Flood, Hodrick, and Kaplan (1986) that stock returns are predictable. Flood, Hodrick, and Kaplan (1986) argued that one could not test for bubbles in stock prices without controlling for the rational movements in stock prices that are caused by fluctuations in expected rates of return. They used annual data and demonstrated that dividend yields, the ratio of the annual dividend to the current stock price, provided statistically significant forecasts of future stock returns, especially at the two-year horizon. Subsequent research by Campbell (1991) and Hodrick (1992) demonstrates that a vector autoregressive approach with monthly data generates significant time-varying forecasts of stock returns at any future horizon and has better small-sample properties than the direct long-horizon approach.

While theories of stock return predictability have been available since Merton (1973), the links between the theories of stock return predictability and the empirical analysis of this issue have been weak. ${ }^{1}$ The intuition of Merton's model is that risk-averse consumer-investors want to hedge against adverse changes in their consumption and investment opportunity sets. Thus, the cross-section and time-series patterns of expected asset returns are determined by more than just the covariances of the returns on the assets with the return on the market portfolio, as in the static capital asset pricing model (CAPM). Expected returns also depend on the covariances of the returns on the assets with the state variables that describe the consumption and investment opportunity sets. The generality of this specification provided little basis for a tight econometric test of Merton's theory.

Predictability of international equity returns is inconsistent with the static CAPM. Some researchers, Harvey (1991), Bekaert and Hodrick (1992), and Ferson and Harvey (1993) for 
example, have characterized the predictability of country returns and developed tests of conditional CAPM's in which the conditional expected return on an asset is related to the conditional expected return on the market portfolio with a conditional, time-varying beta. The main problem with this approach is that it lacks a sound theoretical foundation. Once the conditional distributions are allowed to vary, Merton's (1973) logic indicates that additional hedge portfolios, other than the market, may be priced. This paper develops a formal test of an international, intertemporal, asset-pricing model in which state variables may be priced.

Our analysis builds on the work of Campbell (1993, 1996). The failure of the consumption-based, asset-pricing literature of the 1980's motivated Campbell (1993) to develop a theoretical model that avoids direct measurements of consumption. Campbell (1996) extended this theoretical model and generated empirically testable specifications directly linking the crosssection of expected stock returns to time variation in expected returns on the market portfolio. Campbell (1996) applied his model to a cross-section of returns on 25 portfolios of U.S. stocks taking the value-weighted U.S. market return as the market portfolio. ${ }^{2}$ While the theory was marginally rejected, the pricing errors of the model were small on most portfolios. Most of the explanatory power of the model was in the market portfolio, as is predicted by the CAPM.

The purpose of this paper is to determine whether variation in expected returns on the world market portfolio induces significant hedging motives, which are reflected in average returns across countries. We extend Campbell's (1996) model to an international environment, and we utilize recent evidence of Lamont (1998) to specify the state variables in the forecasting equation.

Our analysis is effectively a constrained arbitrage-pricing model. Korajczyk and Viallet (1989) and Ferson and Harvey (1993) have tested multi-factor, international, arbitrage-pricing 
models. The problem with these specifications is that one must pre-specify the identity and number of factors with little theoretical guidance. Our framework imposes the restriction that the factors affecting the cross-sectional asset pricing must be those that forecast market returns.

As with many studies of international asset pricing, we assume that national equity markets are integrated, with no barriers to investment, transaction costs or differential taxes. We will also assume a representative agent framework, which raises the issue of aggregation across countries and the failure of purchasing power parity, see Adler and Dumas (1983).

Section II provides a review of Campbell's (1996) model. Section III describes the data. Section IV discusses forecasting of real and excess nominal stock returns and compares the results of our analysis with Lamont's (1998) analysis. Section V discusses the econometric aspects of the asset-pricing model, while section VI provides the estimation and testing of the model. Section VII contains concluding remarks.

\section{A Review of Campbell's (1996) Model}

Campbell's (1996) model uses a representative agent framework, and hence, it shares the weaknesses of the consumption CAPM and Euler equation methods that were developed in the 1980 's to test intertemporal asset-pricing models. ${ }^{3}$ Nevertheless, there is an advantage to the approach because Campbell uses log-linearization to eliminate observations on consumption from the asset-pricing model. Ultimately, the model relates expected returns on assets to covariances of returns with the market portfolio, as in the traditional static CAPM, and to covariances of returns with changes in the expected future returns on the market portfolio. ${ }^{4}$

The representative agent's budget constraint is written in real terms as

$$
W_{t+1}=R_{m, t+1}\left(W_{t}-C_{t}\right)
$$


where $W_{t}$ is real wealth, $C_{t}$ is real consumption, and $R_{m, t+1}$ is the gross return on aggregate wealth, which is the return on the market portfolio.

Campbell (1996) divides equation (1) by $W_{t}$ and log-linearizes the resulting expression in a first-order Taylor approximation around the mean $\log$ consumption-wealth ratio, $c-w$. The result is

$$
\Delta w_{t+1}=r_{m, t+1}+k_{w}+(1-(1 / \rho))\left(c_{t}-w_{t}\right),
$$

where lower case letters are natural logarithms of upper case counterparts, $\rho / 1-\exp (c-w)$, and $k_{w}$ is a constant.

When the $\log$ consumption-wealth ratio is stationary, equation (2) implies that the innovation in logarithm of consumption can be written as the innovation in the discounted present value of the return on the market minus the innovation in the discounted present value of consumption growth:

$$
\begin{aligned}
c_{t+1}-E_{t} c_{t+1} & =\left(E_{t+1}-E_{t}\right) \sum_{j=0}^{\infty} \rho^{j} r_{m, t+1+j} \\
& -\left(E_{t+1}-E_{t}\right) \sum_{j=1}^{\infty} \rho^{j} \Delta c_{t+1+j}
\end{aligned}
$$

Equation (3) indicates that an unanticipated increase in consumption today must be due to an innovation in the return on wealth, either today or an expected increase in the future, or it must coincide with a planned reduction in the growth rate of consumption in the future.

Campbell $(1993,1996)$ next uses a log-linear Euler equation to eliminate expected future consumption growth from the right-hand side of equation (3). The consumer's preferences are modeled as in Epstein and Zin (1989) and Weil (1989) with separate parameters for the coefficient of relative risk aversion, $\gamma$, and for the elasticity of intertemporal substitution, F. The objective function is defined recursively by 


$$
U_{t}=\left[(1-\beta) C_{t}^{(1-\gamma) / \theta}+\beta\left(E_{t} U_{t+1}^{(1-\gamma)}\right)^{1 / \theta}\right]^{\theta /(1-\gamma)},
$$

where 2 / $(1-() /[1-(1 / F)]$. Campbell (1996) notes that $\theta$ can have either sign, $\theta \rightarrow 0$ as $\gamma \rightarrow$ $1, \theta \rightarrow 4$ as $\sigma \rightarrow 1$, and $\theta \rightarrow 1$ as $\gamma \rightarrow 1 / \sigma$

Epstein and Zin (1989) solve for the Euler equations associated with maximizing equation (4) subject to the budget constraint given in (1). When asset returns are conditionally homoskedastic and log-normally distributed, the Euler equations may be written in log-linear form as

$$
E_{t} \Delta c_{t+1}=\mu_{m}+\sigma E_{t} r_{m, t+1}
$$

and

$$
E_{t} r_{i, t+1}-r_{f, t+1}+\frac{V_{i i}}{2}=\theta \frac{V_{i c}}{\sigma}+(1-\theta) V_{i m}
$$

In equation (6), $r_{f, t+1}$ is the riskless real interest rate, $V_{i i}=\operatorname{var}\left(r_{i, t+1}-E_{t} r_{i, t+1}\right), V_{i c}=\operatorname{cov}\left(r_{i, t+1}-\right.$ $\left.E_{t} r_{i, t+1}, c_{t+1}-E_{t} c_{t+1}\right)$, and $\mathrm{V}_{\mathrm{im}}=\operatorname{cov}\left(r_{i, t+1}-E_{t} r_{i, t+1}, r_{m, t+1}-E_{t} r_{m, t+1}\right)$

Equation (5) indicates that consumption growth is linearly related to the expected return on the market portfolio, and this fact is used in conjunction with the linearized budget constraint to eliminate consumption from the asset-pricing model. Equation (6) indicates that the continuously compounded risk premium on an asset plus one-half of the asset's variance is determined by the covariances of the asset's return with consumption and with the return on the market.

By substituting equation (5) into equation (3), Campbell (1996) derives

$$
c_{t+1}-E_{t} c_{t+1}=r_{m, t+1}-E_{t} r_{m, t+1}+(1-\sigma)\left(E_{t+1}-E_{t}\right) \sum_{j=1}^{\infty} \rho^{j} r_{m, t+1+j}
$$

Equation (7) indicates that the innovation in consumption, which enters the asset-pricing equation (6), can be eliminated by focusing on the innovations in the return on the market 
portfolio and in the discounted expected future returns. Intuitively, consumption responds onefor-one to the current return on the market portfolio because the objective function is homogeneous of degree one. The response of an innovation in consumption to an innovation in expected future returns depends on income and substitution effects. When the elasticity of substitution, $F$, is less than one, the income effect dominates causing current consumption to rise. When $\mathrm{F}$ is greater than one, the substitution effect dominates; and current consumption falls.

By substituting from equation (7) into the asset-pricing equation (6), we find

$$
\operatorname{cov}\left(r_{i, t+1}-E_{t} r_{i, t+1}, c_{t+1}-E_{t} c_{t+1}\right) \equiv V_{i c}=V_{i m}+(1-\sigma) V_{i h},
$$

where $V_{i h} \equiv \operatorname{cov}\left[r_{i, t+1}-E_{t} r_{i, t+1},\left(E_{t+1}-E_{t}\right) \sum_{j=1}^{\infty} \rho^{j} r_{m, t+1+j}\right]$, which is the covariance of the return on an asset with the revision in expectations about discounted future market returns.

After substituting equation (8) into equation (6) and using the definition of 2, the assetpricing equations become

$$
E_{t} r_{i, t+1}-r_{f, t+1}+\frac{V_{i i}}{2}=\gamma V_{i m}+(\gamma-1) V_{i h} .
$$

Equation (9) demonstrates that an asset's risk premium (adjusted for one-half its own variance) depends on the asset's covariance with the market portfolio, with weight (, and on its covariance with the innovation in discounted expected future market returns, with weight $((-1)$.

The coefficient of relative risk aversion determines the compensation that investors demand for covariance risks. When $(=1$, the model's predictions coincide with those of the static CAPM. When $(>(<)$, investors require higher (lower) expected returns on assets that covary positively with innovations in discounted expected future returns. Campbell (1996) notes that a positive covariance carries a mixed blessing. On the one hand, investors like assets that have good payoffs when expected future returns are high. But, on the other hand, investors 
dislike the fact that such assets provide poor hedging against deterioration in future investment opportunities. When ( is greater than one, the latter effect dominates the former.

While the derivation of equation (9) follows Campbell (1996) in assuming conditional homoskedasticity, Campbell (1993) discusses several conditions under which such an equation can be derived in a more realistic environment of conditional heteroskedasticity. ${ }^{5}$ The most straightforward approach is to assume that the elasticity of substitution, F, equals one. In this case, equation (9) holds in terms of conditional expected returns with all second moments replaced by conditional second moments. Below, we derive and test the unconditional implications of such a specification. ${ }^{6}$

\section{The Data}

Table 1 presents some summary statistics for the primary data set that will be used in our study. We use monthly data from 1970:1 to 1998:4. The first variable is the real return on the MSCI world market portfolio (RRET). The units are percent per month, so the mean return of $0.546 \%$ corresponds to an annualized value of $6.55 \%$. The next four variables are the additional state variables that are the predictors of real returns. The first is the logarithm of the annualized payout-ratio of world dividends relative to world earnings (LOGDE). The second is the logarithm of the annualized world dividend-price ratio (LOGDP). The third is the relative bill rate (RREL), which is the one-month U.S. interest rate minus its previous twelve-month moving average, in percent per month. The fourth variable is the Treasury bond term spread (TSPD) between the 30-year U.S. interest rate and the one-year U.S. interest rate, in percent per month.

The next seven variables in Table 1 are the dollar rates of return on the MSCI G7 country portfolios in excess of the one-month U.S. Treasury bill rate of return. The countries are the United States (US), Japan (JP), Germany (GE), the United Kingdom (UK), France (FR), Canada 
(CA), and Italy (IT). These variables are also measured as percent per month. The mean excess rates of return range from Italy's $1.056 \%$ per annum to the U.K.'s $6.732 \%$ per annum. The U.S. has the lowest standard deviation, and Italy has the highest.

\section{The Forecasting Model}

The first task in developing testable restrictions from equation (9) is to determine that the real return on the world equity market portfolio is forecastable. Since the theoretical model requires multi-period forecasts of the equity return, it is useful to stack the equity return as the first element of a k-dimensional vector of state variables, $z$, and use a vector autoregression (VAR) as in the following:

$$
z_{t+1}=A z_{t}+\varepsilon_{t+1}
$$

The representation of the VAR as a first-order system is not restrictive, as the variables can always be stacked into a first-order companion form. We report the results of the first-order specification as this is the order chosen by the Schwarz (1978) criterion.

Panel A of Table 2 presents a five-variable, first-order vector autoregression. The first variable is the real return on the MSCI world market portfolio (RRET). The other four variables are the payout ratio, LOGDE; the dividend yield, LOGDP; the relative bill rate, RREL; and the term spread, TSPD. We use RREL and TSPD because we are pricing the excess dollar returns on the G7 equities.

Lamont (1998) finds that the payout ratio is an important predictor of the U.S. S\&P 500 excess return. Rozeff (1984), Campbell and Shiller (1988), Fama and French (1988), and Flood, Hodrick and Kaplan (1986) emphasize the importance of the dividend yield in forecasting stock returns at short and long horizons. Campbell (1991) and Hodrick (1992) use the relative bill rate. 
Fama and French (1989) find that the term structure of interest rates predicts stock and bond returns.

For the return forecasting equation, the value of the chi-square statistic with five degrees of freedom is 15.56 , which indicates that real equity returns are predictable at standard levels of statistical significance. Nevertheless, the adjusted $\mathrm{R}^{2}$ for the real return equation is only $3.3 \%$. This pattern of strong statistical significance with low percentage predictability is to be expected in monthly data. In efficient markets, most of the observed return will be unexpected, unless economic agents are extremely risk averse.

The most important features of the other forecasting equations are the coefficients on the own lags, which indicate that there is strong positive serial correlation in the log payout ratio, the $\log$ dividend-price ratio, and the term premium. There are also important off-diagonal terms indicating significant dynamics between the dividend yield, the payout ratio, the relative bill rate, and the term spread.

Panel A of Table 2 also reports the Cumby-Huizinga (1992) L-tests for residual serial correlation of the first eight lags in each equation. Except for the relative bill rate equation, a first-order VAR appears to be a good approximation to the data-generating process.

Panel B of Table 2 reports unconstrained excess return forecasting equations for the G7 countries. Here again, the evidence for predictability of the excess returns is not overwhelmingly strong. These equations are provided as a comparison to the constrained equations that will enter the asset-pricing model.

Table 3 reports the covariances and correlations of the innovations in the VAR. The correlations are in bold above the diagonal. The innovation variance of the real stock return is much larger than the other innovation variances, and the innovation in the real stock return is 
highly negatively correlated with the innovation in the $\log$ dividend yield. The log dividend yield is positively correlated with the log payout ratio and the relative bill rate.

Our results on the predictability of returns present a striking contrast to those of Lamont (1998). We explore these differences in Table 4, which adopts a quarterly measurement interval for comparison purposes. ${ }^{7}$ Lamont (1998) forecasts the excess nominal return on the S\&P 500 and reports a significantly higher $\mathrm{R}^{2}$ for the sample period 1947:Q1 to 1994:Q4. We use Lamont's (1998) data and our programs to produce the first line of Table 4, which coincides with the first line of Lamont's (1998) Table VI. Aside from the higher $\mathrm{R}^{2}$ in the return equation, Lamont (1998) also reports that the dividend-payout ratio positively forecasts returns, which he interprets as a business-cycle effect. The argument is that the payout ratio is countercyclical as earnings fluctuate more than dividends across business cycles. Since expected returns are thought to be countercyclical, being higher in recessions than in booms, the coefficient linking the payout ratio to returns should be positive. Line 2 of Table 4 demonstrates that this effect persists in Lamont's data for the sample period 1970:Q2 to 1994:Q4, which is the part that overlaps most with our sample. Line 3 of Table 4 demonstrates that the effects are not diminished by the inclusion of the term spread in the regression. Line 4 of Table 4 presents an analogous regression to line 3 , but the data are changed. Line 4 uses the excess nominal return on the MSCI-US portfolio, which has a correlation of .997 with the S\&P 500 return, and employs the associated MSCI-US dividend and earning series. LOGDE loses significance, and its sign changes from positive to negative. The $\mathrm{R}^{2}$ for the return equation also falls from .12 to .06. Line 5 of Table 4 demonstrates that extending the sample to 1998:2 causes the dividend yield to lose significance. The last line of Table 4 presents the forecasting regression for the 
MSCI-World excess nominal return, which is similar to the forecasting equation for the real return in Table 1.

\section{Innovations in Forecasts of Future Stock Returns}

The next step in the analysis is to calculate the innovation in the discounted expected future stock returns, since this is the other factor in the asset-pricing framework. To generate the innovation in the discounted present value of the market equity returns from the VAR, define the kdimensional indicator vector e1, whose first element is one and whose other elements are zero. Because $E_{t} z_{t+j}=A^{j} z_{t}$, the innovation in the discounted expected future value of the stock market returns is

$$
\begin{aligned}
\left(E_{t+1}-E_{t}\right) \sum_{j=1}^{\infty} \rho^{j} r_{m, t+1+j} & =e 1^{\prime} \sum_{j=1}^{\infty} \rho^{j} A^{j} \varepsilon_{t+1} \\
& =e 1^{\prime} \rho A(I-\rho A)^{-1} \varepsilon_{t+1} \\
& =\lambda_{h}^{\prime} \varepsilon_{t+1} .
\end{aligned}
$$

The last line of equation (11) defines the vector $8_{\mathrm{h}}$ to be a nonlinear function of the VAR

coefficients equal to e1NDA(I - DA $)^{-1}$. The subscript $h$ is used to identify this coefficient with the hedging demands of investors.

The differences in the variances of the innovations and the correlations between innovations make it hard to interpret the estimation results for a VAR factor model unless the factors are orthogonalized and scaled in some way. To deal with this problem, Campbell (1996) employs Sims's (1980) triangular orthogonalization of the innovations. He also scales the innovations such that they have the same variance as the innovation to the real return. We adopt a similar procedure. Thus, the orthogonalized innovation in the real return is unaffected, and the orthogonalized innovation in the payout ratio is the component of the payout ratio that is orthogonal to the real return. The orthogonalized innovation in the dividend yield is the 
component of the dividend yield that is orthogonal to the real return and the payout ratio, etc. Since fluctuations in the payout ratio are dominated by fluctuations in earnings, the orthogonalized innovation is essentially an earnings shock that is uncorrelated with returns. The orthogonalized innovation in the dividend yield becomes a dividend shock, and the innovations in the relative bill rate and the term premium become shocks to short-term and long-term interest rates that are orthogonal to returns, earnings and dividends.

Table 5 reports the coefficients of $8_{\mathrm{h}}$ for the raw innovations and for the orthogonalized innovations using a $D=0.9949$. Asymptotic standard errors are reported in parentheses under the coefficients. We find that shocks to the dividend yield, the relative bill rate, and the term premium have positive influences on the innovation in discounted expected future returns, while the innovation in the stock return and the payout ratio have a negative effect. Although none of the coefficients is particularly large relative to its standard error, the $P^{2}(5)$ statistic that tests whether all five coefficients are zero is 10.940 , which has a p-value of .053. Hence, the group of variables as a whole does have some predictive power.

Campbell (1996) notes that the coefficient on the orthogonalized innovation to the real return in the $8_{\mathrm{h}}$ vector represents the percent of an innovation in returns that is expected to be reversed over the long run. Our point estimate implies considerably less reversion in international stock returns than Campbell finds in post-war U.S. data. Our coefficient is -0.23, whereas Campbell reports a coefficient of -0.92 . We also find somewhat different results on the importance of the term premium. Here, we find a coefficient on the orthogonalized term premium of 0.65 while Campbell reports 0.21. Since the scale of the orthogonalized variables is quite similar because our variance is 16.42 versus Campbell's 17.04 , fluctuations in the term 
premium are much more important for the international equity markets than for the U.S. domestic market.

Panel B of Table 5 reports the covariances and correlations of the two sources of risk in the asset-pricing model, e1 $\mathbf{d}_{\mathrm{t}+1}$ and $\mathbf{8}_{\mathrm{h}} \mathbf{k}_{\mathrm{t}+1}$. We find that innovations to discounted expected future real returns are slightly more than half as variable as innovations to current returns, whereas Campbell (1996) finds them to be approximately equal, and we find a correlation between the two factors of -.324 , whereas Campbell's is -.915 . The decline in the correlation between e1 $\boldsymbol{d}_{\mathrm{t}+1}$ and $\mathbf{8}_{\mathrm{h}} \boldsymbol{\Lambda}_{\mathrm{t}+1}$ may be due to the decline in the importance of the dividend yield in predicting future stock returns.

\section{The Econometric Asset-Pricing Model}

The next task is to develop the econometric specification to test the asset-pricing model. We use Hansen's (1982) generalized method of moments (GMM), which requires that the econometrician define a set of orthogonality conditions specified by the theoretical model.

Three basic sets of orthogonality conditions are used. The first set is derived from the requirements that the errors in the VAR equations are required to be orthogonal to the righthand-side forecasting variables:

$$
E_{t}\left[\varepsilon_{t+1} \otimes\left(1, z_{t}^{\prime}\right)^{\prime}\right]=0
$$

The second set of orthogonality conditions involves the equations that define the innovations in the excess country returns. Here, as in Panel B of Table 1, the excess rate of return for country $i$ at time $t+1$ is projected onto the same information set, $\left(1,{ }_{\mathbf{l}} \mathbb{N}\right)$, that is used to forecast the real return on the world market portfolio:

$$
r_{i, t+1}-r_{f, t+1}=\mu_{i}+\delta_{i}^{\prime} z_{t}+\eta_{i, t+1}
$$

Thus, the orthogonality conditions for the i-th country excess rate of return are 


$$
E_{t}\left[\eta_{i, t+1} \otimes\left(1, z_{t}^{\prime}\right)^{\prime}\right]=0
$$

The third set of orthogonality conditions involves the asset-pricing equations. Since the asset-pricing equations are written in terms of conditional expectations at time $t$, and the innovations to the first two sets of orthogonality conditions are defined above, the asset-pricing equations (9) can be written as

$$
E_{t} r_{i, t+1}-r_{f, t+1}+\frac{E \eta_{i, t+1}^{2}}{2}=\gamma E_{t}\left(\eta_{i, t+1} e 1^{\prime} \varepsilon_{t+1}\right)+(\gamma-1) E_{t}\left(\eta_{i, t+1} \lambda_{h}^{\prime} \varepsilon_{t+1}\right)
$$

By substituting for the expected return and using realizations for conditional expectations, we can define the innovation in the $\mathrm{i}$-th asset-pricing equation relative to the time $\mathrm{t}$ information set as

$$
u_{i, t+1}=\mu_{i}+\delta_{i}^{\prime} z_{t}+\frac{\eta_{i, t+1}^{2}}{2}-\gamma\left(\eta_{i, t+1} e 1^{\prime} \varepsilon_{t+1}\right)-(\gamma-1)\left(\eta_{i, t+1} \lambda_{h}^{\prime} \varepsilon_{t+1}\right)
$$

In the first set of empirical results, we only impose the orthogonality conditions

$$
E\left(u_{t+1}\right)=0
$$

where $u_{t+1}$ is the vector of the $u_{i, t+1}$ 's. We do not impose additional restrictions because all of the orthogonality conditions of the model must be estimated simultaneously.

With seven country returns and five forecasting variables, there are thirty orthogonality conditions in the first set, forty-two in the second set, and seven in the third for a total of seventy-nine. There are also thirty parameters in the first set, forty-two in the second, and one in the third for a total of seventy-three parameters. Thus, the entire system of equations has six more orthogonality conditions than parameters, and the test of the overidentifying restrictions of the model is a $\mathrm{P}^{2}(6)$. 


\section{Estimation of the Model}

Table 6 reports the seventy-three parameter estimates of the model associated with the VAR forecasting equations, the G7 excess-return forecasting equations, and the asset-pricing equations, as well as the constrained prices of risks. As might be expected, there is little change in the parameters of the VAR forecasting equations or the excess return forecasting equations relative to their respective unconstrained estimates that are reported in Table 1. The key parameter of the model is the coefficient of relative risk aversion, (. Its estimated value is 5.06, with a standard error of 2.54. Often, in the consumption-based asset-pricing literature and in Campbell (1996), the estimated coefficients of relative risk aversion are implausibly large, but our value is quite reasonable.

The overidentifying restrictions of our model are not rejected, since the $\mathrm{P}^{2}(6)$ statistic has a value of 1.23, which corresponds to a p-value of 0.975. Thus, Campbell's dynamic assetpricing model explains the cross-section of the G7 country equity returns. When we estimate the model without imposing the constraint that the coefficient on $V_{\text {in }}$ is $((-1)$, the estimated value of the coefficient is 3.056 with a standard error of 12.330 . The resulting chi-squared test that the coefficient on $V_{\text {ih }}$ equals the coefficient on $V_{\text {im }}$ minus one has a value of 0.004 . The fact that the coefficient on $\mathrm{V}_{\text {ih }}$ is insignificantly different from zero suggests that more restricted models may adequately represent the data.

Test of Restricted Models

There are several conditions that allow the predictions of the dynamic model to collapse to the predictions of the CAPM. This section investigates whether we can reject these conditions or not. 
The first way that the dynamic model reduces to the CAPM is if $(=1$, since then expected returns are determined only by the covariance of an asset with the market portfolio. A GMM likelihood ratio test of the hypothesis that $(=1$ involves estimation of the model under this restriction with the same GMM weighting matrix as is used without the restriction. The difference in the values of the criterion functions is a $\mathrm{P}^{2}(1)=4.512$, which coincides with a $\mathrm{p}$ value of .033 indicating that it is unlikely that $(=1$.

The second way that the model reduces to the CAPM is if the covariances of the asset returns with the hedge portfolio are all zero. The test of these restrictions is a $\mathrm{P}^{2}(7)=54.035$ with a p-value less than .0001 indicating very strong evidence that the covariances with the hedge portfolios are important in pricing the cross-section of asset returns.

The third way that the dynamic model can be reduced to the CAPM is if each $V_{\text {in }}$ is proportional to its $\mathrm{V}_{\mathrm{im}}$ with the same factor of proportionality. The test of these restrictions is a $\mathrm{P}^{2}(6)=4.512$. Hence, we are unable to reject that the dynamic model collapses to the CAPM for this set of assets. The importance of the hedge portfolios in the pricing of the assets indicates that the hedge portfolios might be important in pricing other assets in which the proportionality does not hold.

\section{Estimated Prices of Risks}

The asset-pricing model implies that expected returns on assets adjust to reflect the covariances of asset returns with the return on the market portfolio and with the other underlying factors that forecast the market portfolio. These covariances are the asset's risk characteristics, and the compensations or prices of the risks are constrained by the model. The price of risk that arises from the traditional covariance of an asset's return with the market return is $\left(+\left((-1) 8_{\mathrm{h} 1}\right.\right.$, where $8_{\mathrm{hk}}$ represents the $\mathrm{k}$-th element of $8_{\mathrm{h}}$. The price of the $\mathrm{k}$-th risk that arises from the 
covariance of an asset's return with the innovation in a variable that forecasts the market return is $\left((-1) 8_{\mathrm{hk}}\right.$. Thus, this model provides a clear link between the coefficient of relative risk aversion, (, and the prices of risks that arise from covariances between asset returns and various factors.

The prices of risks are given in Panel $\mathrm{C}$ of Table 6 for the orthogonalized innovations. The covariance of a return with the return on the market portfolio indeed commands the largest price of risk, which justifies the important role of this variable in the traditional CAPM. The estimated price the risk caused by covariance of the return with the market return is 4.065 with a standard error of 1.541. The covariance of a return with the term premium also incurs a large price of risk, a value of 2.411 with a standard error of 1.834 . The prices of other covariance risks are an order of magnitude smaller than these coefficients and have standard errors larger than the coefficients. The results for the prices of risks for the market return and the term premium are comparable to those estimated by Campbell (1996), but he finds much larger prices of risks for the dividend yield and the relative bill rate. These findings are consistent with Korajczyk and Viallet (1989) and Ferson and Harvey (1993) who also find significant risk prices for factors other than the risk generated by covariance with the return on the international market portfolio.

It is also possible to estimate unconstrained prices of risks. That is, the asset-pricing model is simply postulated to be

$$
E_{t} r_{i, t+1}-r_{f, t+1}+\frac{E_{t} \eta_{i, t+1}^{2}}{2}=\sum_{k=1}^{5} \pi_{k} E_{t}\left(\eta_{i, t+1} \varepsilon_{k, t+1}\right)
$$

where the $B_{k}$ parameters represent the five unconstrained prices of risks associated with covariances between the asset returns and the innovations in the factors that forecast the market return. This specification is essentially a five-factor asset-pricing model as in Ross's (1976) arbitrage pricing theory (APT). Table 7 presents the estimated parameters of this model, and the 
unconstrained prices of risk are given at the bottom. Compared to the results of the constrained model, there is a slight reduction in the price of risk associated with the covariance of an asset's return with the real return on the world market portfolio. There are large changes in the prices of the other covariance risks, which are also very imprecisely estimated. Because this model uses the same orthogonality conditions as the constrained model and estimates four additional parameters, the overidentifying restrictions of this unconstrained model also are not rejected. The $\mathrm{P}^{2}(2)$ statistic has a value of 0.133 , which corresponds to a $\mathrm{P}$-value of 0.936.

\section{Pricing Errors from the Dynamic Model}

Table 8 provides the average adjusted excess rates of return for the seven country portfolios for two samples, which have units of percent per month. The first is our base sample of 1970:01 to 1998:04. The second is a sub-sample from 1975:01 to 1995:12, which corresponds to the Fama-French (1998) sample. The average adjusted return corresponds to

$$
\text { Ave. Adj. return } \mathrm{i}=\frac{1}{T-1} \sum_{t=1}^{T-1}\left(r_{i, t+1}-r_{f, t+1}+\frac{\eta_{i, t+1}^{2}}{2}\right)
$$

where the estimated residuals are used. This is simply the average risk premium, which is adjusted for the Jensen's inequality effect that arises because we are using log returns instead of gross returns. The dynamic pricing model predicts that the average adjusted return contains two parts: a part corresponding to risk induced by covariance with the world market portfolio, $\left(\mathrm{V}_{\mathrm{i}, \mathrm{m}}\right.$, and a part corresponding to risk induced by covariance with the innovation in discounted expected future returns, $\left((-1) \mathrm{V}_{\mathrm{i}, \mathrm{h}}\right.$. The model does very well at pricing the average adjusted returns. The pricing error for the U.S. is only 0.001 percent per month or 0.012 percent per annum. The Canadian pricing error is the largest at -0.045 percent per month for the basic 
sample or -0.54 percent per annum. The pricing errors are even smaller, in general, for the Fama-French (1998) sub-sample.

Since the estimates of $\mathrm{V}_{\mathrm{i}, \mathrm{h}}$ are uniformly negative, each equity return covaries negatively with the innovation in discounted expected future market returns. As we noted above, when $(>$ 1, investors view such negative covariation as desirable for hedging purposes. Hence, these terms contribute negatively to the assets' required rates of return.

\section{CAPM Specification Tests}

Our inability to reject the restrictions of the CAPM and the imprecision in the estimates of the unconstrained prices of risks, for the factors other than the market portfolio, suggest that the traditional CAPM may be an adequate representation of the expected returns on the seven country portfolios in the sense of having comparable pricing errors. To investigate this conjecture, we set up the following system of equations:

$$
\begin{aligned}
r_{m, t+1} & =\mu_{m}+\varepsilon_{m, t+1} \\
r_{i, t+1}-r_{f, t+1} & =\mu_{i}+\eta_{i, t+1} \\
u_{i, t+1} & =\mu_{i}+\frac{\eta_{i, t+1}^{2}}{2}-\gamma\left(\eta_{i, t+1} \varepsilon_{m, t+1}\right),
\end{aligned}
$$

for $\mathrm{i}=1, \ldots, 7$. The system is estimated by making each of the error terms orthogonal to a constant. Since there are nine parameters in the system of equations and fifteen orthogonality conditions, the test of the overidentifying restrictions is a $\mathrm{P}^{2}(6)$.

This version of the CAPM is estimated in Panel A of Table 9. For the full sample, the estimated value of ( for is 3.776 , with a standard error of 1.478 . The $\mathrm{P}^{2}(6)$ statistic that tests the overidentifying restrictions of the model is 1.079 , which corresponds to a p-value of 0.982 . Hence, the CAPM is not rejected by the data. The average returns are larger in the sub-sample, but inference about the validity of the CAPM is similar. 
The pricing errors of the CAPM for the two samples are given in Panel B of Table 9. The largest pricing error is again smaller than 0.05 percent per month.

Predictability of returns is generally inconsistent with the CAPM. Only if $\left(=1\right.$, or if $V_{\text {ih }}$ is proportional to $\mathrm{V}_{\mathrm{im}}$, does Campbell's (1996) theory collapse to a conditional CAPM. If the static CAPM is true, the pricing errors should not be predictable with conditioning information. We test this predictability restriction by examining the additional orthogonality conditions that the asset-pricing errors from the CAPM model should be orthogonal to $\mathrm{z}$. Since there are seven assets, five elements in $\mathbf{z}$, and no additional parameters to estimate, we can calculate a $\mathrm{P}^{2}(35)$ statistic directly from the value of the GMM objective function for these thirty-five orthogonality conditions. The value of this statistic is 69.553 , with a p-value of 0.0005 . This indicates considerable evidence against the static CAPM.

Of course, we also did not require the pricing errors of the dynamic model to be orthogonal to the $z$ information set. When we calculate the analogous $\mathrm{P}^{2}(35)$ statistic for these restrictions on the dynamic model, we find a test statistic of 178.87 , with a p-value smaller than .00001. Thus, the dynamic model also fails this test of dynamic asset pricing.

\section{High Book-to-Market Returns}

Fama and French (1998) further demonstrate the inadequacy of the static international CAPM by constructing portfolios of stocks for each country based on book-to-market ratios. ${ }^{8}$ They find that portfolios with high book-to-market (HBM) ratios are particularly troublesome for the CAPM to price. The average returns on high book-to-market firms are significantly higher than those predicted by the CAPM. Our version of these results is presented in Table 10, which excludes Canada because of data availability. Notice that the average adjusted returns on the HBM portfolios are considerably higher than the returns on the value-weighted MSCI market 
portfolios, except in the case of Italy. For example, the average adjusted return for the German HBM portfolio is 0.213 percent per month higher than the German market portfolio. For the U.K. the incremental value is 0.369 . Table 9 indicates that this range is also the magnitude of the pricing errors from the CAPM, as well. The estimation uses the estimated value of ( from the analogous sample for the CAPM estimation with the country market portfolios, and the mean parameters for the HBM return equations are estimated prior to examining the pricing equations.

Table 11 examines whether the dynamic model can successfully price the HBM country portfolios. The answer here, too, is negative. The pricing errors from the dynamic model are approximately equal to the pricing errors from the CAPM.

\section{Conclusions}

This paper develops the implications of stock-return predictability for cross-sectional international asset pricing using the framework developed by Campbell (1996). The dynamic model explains the average returns on the dollar-denominated excess returns on the market portfolios of the G7 countries quite well, but the static CAPM does also. The hedging terms of the dynamic model are non-zero, yet we are unable to reject that they are proportional to covariances with the market portfolio, in which case they have no direct role in the crosssectional international asset pricing. Because the static CAPM is inconsistent with return predictability, which exists in the data, our specification tests demonstrate that instrumental variables can predict the asset-pricing errors from the static CAPM. Unfortunately, these same specification tests reveal that the dynamic model fails along the same dimensions. Neither model can price the high book-to-market country portfolios that Fama and French (1998) construct. 
A rational explanation of the data requires a bridge between the intertemporal predictability of international equity returns and the cross-section of asset returns. Harvey (1991) and Ferson and Harvey (1993) develop an eclectic, empirical approach. Harvey (1991) postulates a conditional CAPM, and Ferson and Harvey (1993) develop conditional beta-pricing models in which expected returns equal the sum of several betas times their associated prices of risks. They allow the betas to vary over time depending on local information, but they require the prices of risks to vary only with global information. The problem with such approaches is that they are not tightly linked to theory.

Fama and French (1996) argue that the static CAPM is flawed, but they develop multifactor explanations of the data. In domestic U.S. asset pricing, they allow expected returns to depend on sensitivities of returns to three factors. The first is the excess return on a broad market portfolio. The second is the difference between the return on a portfolio of smallcapitalization stocks and the return on a portfolio of large-capitalization stocks. The third is the difference between the return on a portfolio of high book-to-market stocks and the return on a portfolio of low book-to-market stocks. For international asset pricing, Fama and French (1998) use two factors: the excess return on the world market portfolio, and the difference in returns between the world high and low book-to-market portfolios. Since the Fama-French (1998) model successfully prices the problematic returns on high book-to-market country portfolios, a risk-based theoretical explanation for the presence of the second risk factor seems plausible. But, Fama and French (1998) note that their tests do not cleanly identify the consumptioninvestment state variables that would link their analysis to intertemporal asset-pricing theories.

The Campbell (1996) model provides a tight theoretical framework that allows us to test the implications of a truly dynamic asset-pricing model of international equity returns. We 
demonstrate that this particular dynamic model provides only a marginal improvement over the static CAPM. Our extension of the model to price international assets involves some strong assumptions. Perhaps the strongest is the assumption of a representative international investor. Adler and Dumas (1983) note that failure of purchasing power parity implies that an international representative investor does not exist. They demonstrate that in such a world expected equity returns depend on hedging terms involving foreign exchange rates. Vassalou (1997) provides some tests of unconditional restrictions implied by this approach by developing indexes of exchange rates and inflation rates. She finds support for the pricing of foreign exchange risk in equity returns. Dumas and Solnik (1995) postulate a version of the AdlerDumas model that allows time-varying world prices of foreign-exchange risk that are postulated to depend on the conditioning information of the econometrician. They, too, find that conditioning information is important and that foreign-exchange risk is priced. De Santis and Gerard (1998) develop tests of the Adler-Dumas model using a conditional approach that estimates parametric conditional means and covariances. Since there is strong evidence against purchasing power parity, modifying the model to allow for different real returns in different countries is an extension that we are pursuing.

Another weakness of our approach is its assumption that the value-weighted real stock return correctly measures the return on real wealth. Both Jagannathan and Wang (1996) and Campbell (1996) stress the importance of labor income and human capital in asset pricing. While Jagannathan and Wang (1996) and Campbell (1996) treat labor income as tradeable in a domestic asset-pricing context, such an assumption appears untenable in a multicountry model. Unfortunately, the required extension of the Campbell (1996) model to allow non-traded human wealth in different countries appears non-trivial. 
As Flood, Hodrick, and Kaplan (1986) note, asset return predictability is not inconsistent with rational, maximizing behavior. Indeed, modern asset-pricing theories link this return predictability to hedging motives of investors. Different sensitivities of asset returns to the underlying state variables that generate time-varying market returns cause risk premiums on the assets to differ. This paper investigates the links between return predictability and the crosssection of country returns. Hedging demands may play a role in cross-sectional asset pricing, but there are still many puzzles that remain to be investigated. 


\section{References}

Adler, Michael, and Bernard Dumas, 1983, "International Portfolio Choice and Corporation Finance: A Synthesis,” Journal of Finance 38, 925-984.

Bekaert, Geert and Robert J. Hodrick, 1992, “Characterizing Predictable Components in Excess Returns on Equity and Foreign Exchange Markets," Journal of Finance 47, 467-510.

Campbell, John Y., 1991, “A Variance Decomposition for Stock Returns,” Economic Journal 101, 157-179.

Campbell, John Y., 1993, "Intertemporal Asset Pricing Without Consumption," American Economic Review 83,487-512.

Campbell, John Y., 1996, "Understanding Risk and Return,” Journal of Political Economy 104, 298-345.

Campbell, John Y., and Robert J. Shiller, 1988, “The Dividend-Price Ratio and Expectations of Future Dividends and Discount Factors," Review of Financial Studies 1, 195-228.

Chang, Jow-ran and Mao-wei Hung, 1999, “An International Asset Pricing Model With Timevarying Hedging Risk," manuscript, National Taiwan University.

Cumby, Robert E. and John Huizinga, 1992, "Testing the Autocorrelation Structure of Disturbances in Ordinary Least Squares and Instrumental Variables Regressions," Econometrica 60, 185-196.

De Santis, Giorgio, and Bruno Gerard, 1998, "How Big Is the Premium for Currency Risk," Journal of Financial Economics 49, 375-412.

Dumas, Bernard, and Bruno Solnik, 1995, “The World Price of Foreign Exchange Risk,” Journal of Finance 50, 445-479. 
Epstein, Larry G., and Stanley E. Zin, 1989, "Substitution, Risk Aversion, and the Temporal Behavior of Consumption and Asset Returns," Econometrica 57, 937-969.

Fama, Eugene F., and Kenneth R. French, 1988, "Dividend Yields and Expected Stock Returns," Journal of Financial Economics 22, 3-26.

Fama, Eugene F., and Kenneth R. French, 1989, "Business Conditions and Expected Returns on Stocks and Bonds," Journal of Financial Economics 25, 23-50.

Fama, Eugene F., and Kenneth R. French, 1996, "Multifactor Explanations of Asset Pricing Anomalies," Journal of Finance 51, 55-84.

Fama, Eugene F., and Kenneth R. French, 1998, "Value versus Growth: The International Evidence," Journal of Finance 53, 1975-1999.

Ferson, Wayne E., and Campbell R. Harvey, 1993, “The Risk and Predictability of International Equity Returns," Review of Financial Studies 6, 527-566.

Flood, Robert. P., Robert J. Hodrick, and Paul Kaplan, 1986, “An Evaluation of Recent Evidence on Stock Market Bubbles," Northwestern University Working Paper. Reprinted in Peter M. Garber and Robert P. Flood, eds., 1994, Speculative Bubbles, Speculative Attacks, and Policy Switching, Cambridge: MIT Press, 105-133.

Giovannini, Alberto and Philippe Weil, 1989, "Risk Aversion and Intertemporal Substitution in the Capital Asset Pricing Model,” NBER Working Paper No. 2824, January.

Hansen, Lars Peter, 1982, "Large Sample Properties of Generalized Method of Moments Estimators," Econometrica 50, 1029-1054.

Hansen, Lars Peter, and Kenneth J. Singleton, 1982, "Generalized Instrumental Variables Estimation of Nonlinear Rational Expectation Models," Econometrica 50, 1269-1286. 
Harvey, Campbell, 1991, “The World Price of Covariance Risk,” Journal of Finance 46, 111157.

Hodrick, Robert J., 1981, “International Asset Pricing with Time-Varying Risk Premia,” Journal of International Economics 11, 573-587.

Hodrick, Robert J., 1992, "Dividend Yields and Expected Stock Returns: Alternative Procedures for Inference and Measurement," Review of Financial Studies 5, 357-386.

Jagannathan, Ravi, and Zhenyu Wang, 1996, "The Conditional CAPM and the Cross-Section of Expected Returns," Journal of Finance 51, 3-53.

Korajczyk, Robert A. and Claude J. Viallet, 1989, “An Empirical Investigation of International Asset Pricing," Review of Financial Studies 2, 553-586.

Lamont, Owen, 1998, “Earnings and Expected Returns,” Journal of Finance 53, 1563-1587.

Merton, Robert C., 1973, “An Intertemporal Capital Asset Pricing Model,” Econometrica 41, 867-87.

Ross, Stephen A., 1976, “The Arbitrage Theory of Capital Asset Pricing," Journal of Economic Theory 13, 341-360.

Rozeff, Michael, 1984, "Dividend Yields Are Equity Risk Premiums," Journal of Portfolio Management 11, 68-75.

Schwarz, Gideon, 1978, "Estimating the Dimension of a Model," Annals of Statistics 6, 461-464.

Sims, Christopher A., 1980, "Macroeconomics and Reality,” Econometrica 48, 1-48.

Vassalou, Maria, 1997, "Exchange Rate and Foreign Inflation Risk Premiums in Global Equity Returns," Columbia University Working Paper.

Weil, Philippe, 1989, “The Equity Premium Puzzle and the Risk-Free Rate Puzzle,” Journal of Monetary Economics 24, 401-421. 


\section{Table 1: Summary Statistics}

The sample period is 1970:01 to 1998:04. The variables are the monthly real return on the MSCI world market portfolio (RRET), the logarithm of world dividends relative to world earnings (LOGDE), the logarithm of the world dividend-price ratio (LOGDP), the one-month U.S. Treasury bill interest rate minus its twelve-month moving average (RREL), the 30-year minus one-year U.S. Treasury bond term spread (TSPD), and the dollar rates of return on the G7 countries' equities in excess of the U.S. Treasury bill rate.

\begin{tabular}{ccccc}
\hline \hline & Mean & Std.Dev. & Minimum & Maximum \\
\hline RRET & 0.546 & 4.166 & -18.849 & 13.342 \\
LOGDE & -0.744 & 0.118 & -0.965 & -0.483 \\
LOGDP & -5.946 & 0.343 & -6.641 & -5.348 \\
RREL & -0.003 & 0.117 & -0.489 & 0.440 \\
TSPD & 0.087 & 0.113 & -0.281 & 0.359 \\
EXRET-US & 0.464 & 4.363 & -24.306 & 15.570 \\
EXRET-JP & 0.488 & 6.529 & -21.788 & 21.162 \\
EXRET-GE & 0.485 & 5.854 & -20.080 & 17.337 \\
EXRET-UK & 0.561 & 6.845 & -24.701 & 44.048 \\
EXRET-FR & 0.447 & 6.723 & -28.154 & 23.622 \\
EXRET-CA & 0.290 & 5.366 & -25.776 & 15.487 \\
EXRET-IT & 0.088 & 7.578 & -24.613 & 26.441 \\
\hline
\end{tabular}


Table 2: Fundamental VAR and Forecasting Equations

Panel A contains a five variable VAR in the real return on the MSCI world market portfolio (RRET), the logarithm of dividends relative to earnings (LOGDE), the logarithm of the dividend-price ratio (LOGDP), the one-month Treasury bill interest rate minus its twelve-month moving average (RREL), and the 30-year minus one-year Treasury bond term spread (TSPD). The sample period is 1970:01 to 1998:04. Regressions in Panel B project excess dollar returns on the G7 countries onto the same information set as the VAR. The joint predictability test examines the predictive power of the five lagged variables. The Cumby-Huizinga (1992) L-test is a joint test that the first eight autocorrelations of the residuals are all zero.

\begin{tabular}{|c|c|c|c|c|c|c|c|c|c|}
\hline \multirow[b]{2}{*}{$\begin{array}{l}\text { Dependent } \\
\text { Variable }\end{array}$} & \multicolumn{6}{|c|}{ Coefficients on Regressors } & \multirow{2}{*}{\multicolumn{2}{|c|}{$\begin{array}{c}\text { Joint } \\
\text { predictability } \\
\chi^{2}(5) \\
\text { p-value }\end{array}$}} & \multirow{2}{*}{$\begin{array}{l}\text { L-test } \\
\chi^{2}(8) \\
\text { p-value }\end{array}$} \\
\hline & $\begin{array}{c}\text { RRET } \\
\text { (std.err.) }\end{array}$ & $\begin{array}{l}\text { LOGDE } \\
\text { (std.err.) }\end{array}$ & $\begin{array}{l}\text { LOGDP } \\
\text { (std.err.) }\end{array}$ & $\begin{array}{l}\text { RREL } \\
\text { (std.err.) }\end{array}$ & $\begin{array}{c}\text { TSPD } \\
\text { (std.err.) }\end{array}$ & $\begin{array}{l}\text { CONST } \\
\text { (std.err.) }\end{array}$ & & & \\
\hline \multicolumn{10}{|c|}{ Panel A: Fundamental VAR } \\
\hline RRET & $\begin{array}{c}0.058 \\
(0.063)\end{array}$ & $\begin{array}{l}-3.998 \\
(2.134)\end{array}$ & $\begin{array}{c}1.073 \\
(0.751)\end{array}$ & $\begin{array}{c}0.892 \\
(2.190)\end{array}$ & $\begin{array}{c}9.577 \\
(3.052)\end{array}$ & $\begin{array}{c}3.110 \\
(4.234)\end{array}$ & 0.033 & $\begin{array}{l}15.56 \\
0.01\end{array}$ & $\begin{array}{l}13.08 \\
0.11\end{array}$ \\
\hline LOGDE & $\begin{array}{l}-0.0001 \\
(0.0003)\end{array}$ & $\begin{array}{c}0.963 \\
(0.017)\end{array}$ & $\begin{array}{c}0.005 \\
(0.004)\end{array}$ & $\begin{array}{c}-0.038 \\
(0.015)\end{array}$ & $\begin{array}{c}0.011 \\
(0.019)\end{array}$ & $\begin{array}{l}0.0002 \\
(0.022)\end{array}$ & 0.949 & $\begin{array}{l}8847 \\
0.00\end{array}$ & $\begin{array}{l}14.80 \\
0.06\end{array}$ \\
\hline LOGDP & $\begin{array}{l}-0.0010 \\
(0.0006)\end{array}$ & $\begin{array}{c}0.015 \\
(0.022)\end{array}$ & $\begin{array}{c}0.986 \\
(0.008)\end{array}$ & $\begin{array}{l}-0.001 \\
(0.021)\end{array}$ & $\begin{array}{l}-0.081 \\
(0.030)\end{array}$ & $\begin{array}{l}-0.067 \\
(0.045)\end{array}$ & 0.985 & $\begin{array}{l}19698 \\
0.00\end{array}$ & $\begin{array}{l}11.56 \\
0.17\end{array}$ \\
\hline RREL & $\begin{array}{l}-0.0023 \\
(0.0013)\end{array}$ & $\begin{array}{c}0.111 \\
(0.039)\end{array}$ & $\begin{array}{l}-0.057 \\
(0.016)\end{array}$ & $\begin{array}{c}0.580 \\
(0.061)\end{array}$ & $\begin{array}{l}-0.353 \\
(0.071)\end{array}$ & $\begin{array}{l}-0.223 \\
(0.082)\end{array}$ & 0.621 & $\begin{array}{l}360.4 \\
0.00\end{array}$ & $\begin{array}{c}49.14 \\
0.00\end{array}$ \\
\hline TSPD & $\begin{array}{l}-0.0011 \\
(0.0007)\end{array}$ & $\begin{array}{c}0.017 \\
(0.017)\end{array}$ & $\begin{array}{c}0.001 \\
(0.007)\end{array}$ & $\begin{array}{c}0.016 \\
(0.031)\end{array}$ & $\begin{array}{c}0.951 \\
(0.030)\end{array}$ & $\begin{array}{c}0.022 \\
(0.036)\end{array}$ & 0.894 & $\begin{array}{l}2139 \\
0.00\end{array}$ & $\begin{array}{l}8.69 \\
0.37\end{array}$ \\
\hline \multicolumn{10}{|c|}{ Panel B: Forecasting Equations } \\
\hline EXRET-US & $\begin{array}{c}0.0043 \\
(0.0726)\end{array}$ & $\begin{array}{l}-4.446 \\
(2.251)\end{array}$ & $\begin{array}{c}0.532 \\
(0.853)\end{array}$ & $\begin{array}{l}-0.588 \\
(2.598)\end{array}$ & $\begin{array}{c}7.322 \\
(3.433)\end{array}$ & $\begin{array}{l}-0.293 \\
(4.716)\end{array}$ & 0.015 & $\begin{array}{l}10.65 \\
0.06\end{array}$ & $\begin{array}{l}9.40 \\
0.31\end{array}$ \\
\hline EXRET-JP & $\begin{array}{c}0.1846 \\
(0.1056)\end{array}$ & $\begin{array}{c}1.450 \\
(3.328)\end{array}$ & $\begin{array}{c}2.643 \\
(1.075)\end{array}$ & $\begin{array}{c}2.652 \\
(3.402)\end{array}$ & $\begin{array}{l}10.303 \\
(4.085)\end{array}$ & $\begin{array}{l}16.294 \\
(6.200)\end{array}$ & 0.033 & $\begin{array}{l}16.16 \\
0.01\end{array}$ & $\begin{array}{l}6.11 \\
0.63\end{array}$ \\
\hline EXRET-GE & $\begin{array}{c}0.0252 \\
(0.0995)\end{array}$ & $\begin{array}{l}-5.413 \\
(2.897)\end{array}$ & $\begin{array}{c}0.659 \\
(0.981)\end{array}$ & $\begin{array}{c}-0.248 \\
(2.986)\end{array}$ & $\begin{array}{c}9.781 \\
(4.045)\end{array}$ & $\begin{array}{l}-0.493 \\
(5.795)\end{array}$ & 0.013 & $\begin{array}{l}8.99 \\
0.11\end{array}$ & $\begin{array}{l}11.59 \\
0.17\end{array}$ \\
\hline EXRET-UK & $\begin{array}{c}0.0331 \\
(0.1000)\end{array}$ & $\begin{array}{l}-7.339 \\
(3.970)\end{array}$ & $\begin{array}{c}1.943 \\
(1.507)\end{array}$ & $\begin{array}{c}1.149 \\
(3.368)\end{array}$ & $\begin{array}{l}13.971 \\
(5.681)\end{array}$ & $\begin{array}{c}5.432 \\
(7.295)\end{array}$ & 0.019 & $\begin{array}{l}8.42 \\
0.13\end{array}$ & $\begin{array}{l}4.95 \\
0.76\end{array}$ \\
\hline EXRET-FR & $\begin{array}{c}0.0187 \\
(0.0879)\end{array}$ & $\begin{array}{l}-5.009 \\
(3.102)\end{array}$ & $\begin{array}{c}0.930 \\
(1.245)\end{array}$ & $\begin{array}{c}1.288 \\
(3.539)\end{array}$ & $\begin{array}{l}11.221 \\
(4.825)\end{array}$ & $\begin{array}{c}1.297 \\
(6.778)\end{array}$ & 0.007 & $\begin{array}{l}6.67 \\
0.25\end{array}$ & $\begin{array}{l}7.06 \\
0.53\end{array}$ \\
\hline EXRET-CA & $\begin{array}{c}0.1521 \\
(0.0656)\end{array}$ & $\begin{array}{l}-1.505 \\
(2.676)\end{array}$ & $\begin{array}{c}0.685 \\
(1.050)\end{array}$ & $\begin{array}{c}3.025 \\
(3.330)\end{array}$ & $\begin{array}{c}5.018 \\
(4.915)\end{array}$ & $\begin{array}{c}2.726 \\
(5.740)\end{array}$ & 0.006 & $\begin{array}{l}7.28 \\
0.20\end{array}$ & $\begin{array}{c}11.58 \\
0.17\end{array}$ \\
\hline EXRET-IT & $\begin{array}{c}0.1121 \\
(0.0914)\end{array}$ & $\begin{array}{l}-6.785 \\
(3.568)\end{array}$ & $\begin{array}{c}0.223 \\
(1.294)\end{array}$ & $\begin{array}{c}2.422 \\
(3.812)\end{array}$ & $\begin{array}{c}8.790 \\
(4.694)\end{array}$ & $\begin{array}{l}-4.457 \\
(7.179)\end{array}$ & 0.004 & $\begin{array}{l}8.96 \\
0.11\end{array}$ & $\begin{array}{l}13.63 \\
0.09\end{array}$ \\
\hline
\end{tabular}




\section{Table 3: Covariances and Correlations of VAR Residuals}

This table reports the covariances and correlations of the VAR residuals from Table 2. The correlations are in bold above the diagonal. The variables are the real return on the MSCI world market portfolio (RRET), the logarithm of dividends relative to earnings (LOGDE), the logarithm of the dividend-price ratio (LOGDP), the one-month Treasury bill interest rate minus its twelve-month moving average (RREL), and the 30-year minus one-year Treasury bond term spread (TSPD). The sample period is 1970:01 to 1998:04.

\begin{tabular}{llllll}
\hline \hline & RRET & LOGDE & LOGDP & RREL & TSPD \\
\hline RRET & 16.4194 & $\mathbf{0 . 0 6 2 8}$ & $\mathbf{- 0 . 8 6 2 9}$ & $\mathbf{- 0 . 1 0 0 7}$ & $\mathbf{0 . 1 2 4 6}$ \\
LOGDE & 0.0067 & 0.0007 & $\mathbf{0 . 2 1 4 4}$ & $\mathbf{0 . 0 4 8 1}$ & $\mathbf{0 . 0 8 5 1}$ \\
LOGDP & -0.1474 & 0.0002 & 0.0018 & $\mathbf{0 . 1 5 0 2}$ & $\mathbf{- 0 . 0 6 1 2}$ \\
RREL & -0.0292 & 0.0001 & 0.0005 & 0.0051 & $\mathbf{- 0 . 0 4 9 0}$ \\
TSPD & 0.0183 & 0.0001 & 0.0001 & 0.0001 & 0.0013 \\
\hline
\end{tabular}




\section{Table 4: Quarterly Return Forecasting Equations}

This table compares equity return forecasting equations using quarterly data. The first three rows use data from Lamont (1998), and the dependent variable is the excess return on the S\&P 500. The last three rows use excess return data from the MSCI-US or the MSCI-World indexes. For Lamont's data, the regressors are the lagged excess return (RET), the logarithm of S\&P dividends relative to S\&P earnings (LOGDE), the logarithm of the S\&P dividend-price ratio (LOGDP), the one-month Treasury bill interest rate minus its twelve-month moving average sampled at the end of the quarter (RREL), and the long-term government bond yield minus the T-bill yield (TSPD). For the MSCI regressions, the regressors are the lagged MSCI return (RET), the logarithm of MSCI dividends relative to MSCI earnings (LOGDE), the logarithm of the MSCI dividend-price ratio (LOGDP), the three-month Treasury bill interest rate minus its four-quarter moving average (RREL), and the 30-year minus one-year Treasury bond term spread (TSPD).

\begin{tabular}{|c|c|c|c|c|c|c|c|c|}
\hline Data & $\begin{array}{l}\text { Constant } \\
\text { (std.err.) }\end{array}$ & $\begin{array}{c}\text { RET } \\
\text { (std.err.) }\end{array}$ & $\begin{array}{l}\text { LOGDP } \\
\text { (std.err.) }\end{array}$ & $\begin{array}{l}\text { LOGDE } \\
\text { (std.err.) }\end{array}$ & $\begin{array}{c}\text { RREL } \\
\text { (std.err.) }\end{array}$ & $\begin{array}{c}\text { TSPD } \\
\text { (std.err.) }\end{array}$ & 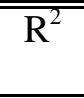 & Sample \\
\hline $\begin{array}{c}\text { Lamont } \\
(\mathrm{S} \& \mathrm{P})\end{array}$ & $\begin{array}{c}0.209 \\
(0.062)\end{array}$ & $\begin{array}{c}0.066 \\
(0.069)\end{array}$ & $\begin{array}{c}0.078 \\
(0.020)\end{array}$ & $\begin{array}{c}0.086 \\
(0.030)\end{array}$ & $\begin{array}{l}-0.892 \\
(0.465)\end{array}$ & & 0.13 & $\begin{array}{c}\text { 47:Q1 - } \\
\text { 94:Q4 }\end{array}$ \\
\hline $\begin{array}{c}\text { Lamont } \\
\text { (S\&P) }\end{array}$ & $\begin{array}{c}0.284 \\
(0.118)\end{array}$ & $\begin{array}{c}0.037 \\
(0.099)\end{array}$ & $\begin{array}{c}0.105 \\
(0.039)\end{array}$ & $\begin{array}{c}0.103 \\
(0.046)\end{array}$ & $\begin{array}{l}-0.777 \\
(0.604)\end{array}$ & & 0.12 & $\begin{array}{c}\text { 70:Q2 - } \\
\text { 94:Q4 }\end{array}$ \\
\hline $\begin{array}{l}\text { Lamont } \\
(\mathrm{S} \& \mathrm{P})\end{array}$ & $\begin{array}{c}0.352 \\
(0.131)\end{array}$ & $\begin{array}{c}0.034 \\
(0.099)\end{array}$ & $\begin{array}{c}0.126 \\
(0.043)\end{array}$ & $\begin{array}{c}0.093 \\
(0.047)\end{array}$ & $\begin{array}{l}-0.433 \\
(0.668)\end{array}$ & $\begin{array}{c}3.712 \\
(3.096)\end{array}$ & 0.12 & $\begin{array}{c}\text { 70:Q2 - } \\
94: Q 4\end{array}$ \\
\hline MSCI - US & $\begin{array}{c}0.275 \\
(0.316)\end{array}$ & $\begin{array}{c}0.015 \\
(0.103)\end{array}$ & $\begin{array}{c}0.076 \\
(0.044)\end{array}$ & $\begin{array}{l}-0.033 \\
(0.083)\end{array}$ & $\begin{array}{l}-3.669 \\
(2.935)\end{array}$ & $\begin{array}{c}5.104 \\
(3.655)\end{array}$ & 0.06 & $\begin{array}{c}\text { 70:Q2 - } \\
94: \mathrm{Q}^{4}\end{array}$ \\
\hline MSCI - US & $\begin{array}{l}-0.238 \\
(0.162)\end{array}$ & $\begin{array}{c}0.035 \\
(0.098)\end{array}$ & $\begin{array}{c}0.010 \\
(0.027)\end{array}$ & $\begin{array}{l}-0.137 \\
(0.061)\end{array}$ & $\begin{array}{l}-4.032 \\
(2.751)\end{array}$ & $\begin{array}{c}5.190 \\
(3.512)\end{array}$ & 0.06 & $\begin{array}{l}\text { 70:Q2 - } \\
98: \mathrm{Q}^{2}\end{array}$ \\
\hline $\begin{array}{l}\text { MSCI - } \\
\text { World }\end{array}$ & $\begin{array}{l}-0.058 \\
(0.168)\end{array}$ & $\begin{array}{l}-0.024 \\
(0.099)\end{array}$ & $\begin{array}{c}0.022 \\
(0.026)\end{array}$ & $\begin{array}{l}-0.075 \\
(0.072)\end{array}$ & $\begin{array}{l}-1.834 \\
(2.781)\end{array}$ & $\begin{array}{c}6.310 \\
(3.543)\end{array}$ & 0.03 & $\begin{array}{c}\text { 70:Q2 - } \\
\text { 98:Q2 }\end{array}$ \\
\hline
\end{tabular}




\section{Table 5: Innovations to the Long-Run Stock Return}

Panel A reports the coefficients of the vector defining the innovation in the discounted present value of the future world stock market returns in equation (11). The variables of the VAR are the real return on the MSCI world market portfolio (RRET), the logarithm of dividends relative to earnings (LOGDE), the logarithm of the dividend-price ratio (LOGDP), the one-month Treasury bill interest rate minus its twelve-month moving average (RREL), and the 30-year minus one-year Treasury bond term spread (TSPD). The sample period is 1970:01 to 1998:04. The $P^{2}(5)$ test examines whether the five coefficients are jointly equal to zero. The second set of coefficients is orthogonalized by triangularizing the innovations and scaling them to have the same variance as the innovation in the real return. Panel B reports the covariances and correlation (in bold) of the innovation in the real return and the innovation in the discounted expected future returns.

\begin{tabular}{|c|c|c|c|c|c|}
\hline \multicolumn{6}{|c|}{ Panel A: Coefficients of $8_{\mathrm{h}}$} \\
\hline \multirow[b]{2}{*}{ Orthogonalized } & \multicolumn{5}{|c|}{ Shocks to } \\
\hline & $\begin{array}{c}\text { RRET } \\
\text { (std.err.) }\end{array}$ & $\begin{array}{l}\text { LOGDE } \\
\text { (std.err.) }\end{array}$ & $\begin{array}{l}\text { LOGDP } \\
\text { (std.err.) }\end{array}$ & $\begin{array}{c}\text { RREL } \\
\text { (std.err.) }\end{array}$ & $\begin{array}{c}\text { TSPD } \\
\text { (std.err.) }\end{array}$ \\
\hline No & $\begin{array}{l}-0.064 \\
(079)\end{array}$ & $\begin{array}{l}-30.576 \\
(43078)\end{array}$ & $\begin{array}{c}25.043 \\
35378)\end{array}$ & $\begin{array}{c}7.431 \\
(7692)\end{array}$ & $\begin{array}{c}73.547 \\
(60299)\end{array}$ \\
\hline Yes & $\begin{array}{l}-0.233 \\
(0.342)\end{array}$ & $\begin{array}{l}-0.070 \\
(0.305)\end{array}$ & $\begin{array}{c}0.165 \\
(0.135)\end{array}$ & $\begin{array}{c}0.098 \\
(0.137)\end{array}$ & $\begin{array}{c}0.649 \\
(0.532)\end{array}$ \\
\hline $\begin{array}{c}\mathrm{P}^{2}(5) \\
\mathrm{p} \text {-value }\end{array}$ & $\begin{array}{l}10.940 \\
0.053\end{array}$ & & & & \\
\hline \multicolumn{6}{|c|}{ Panel B: Covariance and Correlation of News Variable } \\
\hline & $\begin{array}{l}e 1 N_{t+1} \\
8 h N_{t+1}\end{array}$ & $\begin{array}{l}\mathrm{e} 1 \mathrm{~N}_{\mathrm{t}+1} \\
16.419 \\
-3.819\end{array}$ & $\begin{array}{c}8 \mathrm{~N}_{\mathrm{t}+1} \\
\mathbf{- 0 . 3 2 4} \\
8.485\end{array}$ & & \\
\hline
\end{tabular}


Table 6: GMM Estimates of the Constrained Model

\begin{tabular}{|c|c|c|c|c|c|c|}
\hline \multirow[b]{2}{*}{$\begin{array}{c}\text { Dependent } \\
\text { Variable }\end{array}$} & \multicolumn{6}{|c|}{ Coefficients on Regressors } \\
\hline & $\begin{array}{c}\text { RRET } \\
\text { (std.err.) }\end{array}$ & $\begin{array}{l}\text { LOGDE } \\
\text { (std.err.) }\end{array}$ & $\begin{array}{l}\text { LOGDP } \\
\text { (std.err.) }\end{array}$ & $\begin{array}{c}\text { RREL } \\
\text { (std.err.) }\end{array}$ & $\begin{array}{c}\text { TSPD } \\
\text { (std.err.) }\end{array}$ & $\begin{array}{l}\text { CONST } \\
\text { (std.err.) }\end{array}$ \\
\hline \multicolumn{7}{|c|}{ Panel A: VAR } \\
\hline RRET & $\begin{array}{c}0.0666 \\
(0.0620)\end{array}$ & $\begin{array}{l}-3.751 \\
(2.071)\end{array}$ & $\begin{array}{c}1.082 \\
(0.713)\end{array}$ & $\begin{array}{c}0.715 \\
(2.159)\end{array}$ & $\begin{array}{c}9.022 \\
(2.960)\end{array}$ & $\begin{array}{c}3.385 \\
(4.064)\end{array}$ \\
\hline LOGDE & $\begin{array}{c}0.0000 \\
(0.0003)\end{array}$ & $\begin{array}{c}0.964 \\
(0.017)\end{array}$ & $\begin{array}{c}0.004 \\
(0.004)\end{array}$ & $\begin{array}{l}-0.038 \\
(0.015)\end{array}$ & $\begin{array}{c}0.010 \\
(0.019)\end{array}$ & $\begin{array}{l}-0.003 \\
(0.022)\end{array}$ \\
\hline LOGDP & $\begin{array}{l}-0.0010 \\
(0.0006)\end{array}$ & $\begin{array}{c}0.012 \\
(0.022)\end{array}$ & $\begin{array}{c}0.986 \\
(0.008)\end{array}$ & $\begin{array}{l}0.0002 \\
(0.021)\end{array}$ & $\begin{array}{l}-0.076 \\
(0.030)\end{array}$ & $\begin{array}{l}-0.071 \\
(0.043)\end{array}$ \\
\hline RREL & $\begin{array}{c}-0.0023 \\
(0.0013)\end{array}$ & $\begin{array}{c}0.112 \\
(0.038)\end{array}$ & $\begin{array}{l}-0.057 \\
(0.016)\end{array}$ & $\begin{array}{c}0.570 \\
(0.060)\end{array}$ & $\begin{array}{l}-0.359 \\
(0.069)\end{array}$ & $\begin{array}{l}-0.227 \\
(0.081)\end{array}$ \\
\hline TSPD & $\begin{array}{l}-0.0011 \\
(0.0007)\end{array}$ & $\begin{array}{c}0.017 \\
(0.017)\end{array}$ & $\begin{array}{l}0.0004 \\
(0.007)\end{array}$ & $\begin{array}{c}0.017 \\
(0.031)\end{array}$ & $\begin{array}{c}0.950 \\
(0.029)\end{array}$ & $\begin{array}{c}0.021 \\
(0.035)\end{array}$ \\
\hline \multicolumn{7}{|c|}{ Panel B: Forecasting equations } \\
\hline EXRET-US & $\begin{array}{c}0.0136 \\
(0.0700)\end{array}$ & $\begin{array}{l}-4.201 \\
(2.166)\end{array}$ & $\begin{array}{c}0.533 \\
(0.831)\end{array}$ & $\begin{array}{c}-0.871 \\
(2.552)\end{array}$ & $\begin{array}{c}6.721 \\
(3.352)\end{array}$ & $\begin{array}{c}-0.093 \\
(4.616)\end{array}$ \\
\hline EXRET-JP & $\begin{array}{c}0.190 \\
(0.104)\end{array}$ & $\begin{array}{c}1.735 \\
(3.286)\end{array}$ & $\begin{array}{c}2.634 \\
(1.036)\end{array}$ & $\begin{array}{c}2.728 \\
(3.315)\end{array}$ & $\begin{array}{l}10.194 \\
(4.017)\end{array}$ & $\begin{array}{l}16.492 \\
(6.050)\end{array}$ \\
\hline EXRET-GE & $\begin{array}{c}0.039 \\
(0.097)\end{array}$ & $\begin{array}{l}-4.917 \\
(2.848)\end{array}$ & $\begin{array}{c}0.631 \\
(0.962)\end{array}$ & $\begin{array}{l}-0.677 \\
(2.934)\end{array}$ & $\begin{array}{c}8.791 \\
(3.867)\end{array}$ & $\begin{array}{l}-0.269 \\
(5.685)\end{array}$ \\
\hline EXRET-UK & $\begin{array}{l}0.0453 \\
(0.099)\end{array}$ & $\begin{array}{l}-6.909 \\
(3.753)\end{array}$ & $\begin{array}{c}1.940 \\
(1.357)\end{array}$ & $\begin{array}{c}1.101 \\
(3.361)\end{array}$ & $\begin{array}{l}12.762 \\
(5.432)\end{array}$ & $\begin{array}{c}5.798 \\
(6.547)\end{array}$ \\
\hline EXRET-FR & $\begin{array}{c}0.025 \\
(0.087)\end{array}$ & $\begin{array}{l}-4.927 \\
(3.037)\end{array}$ & $\begin{array}{c}1.005 \\
(1.151)\end{array}$ & $\begin{array}{c}0.725 \\
(3.441)\end{array}$ & $\begin{array}{l}10.621 \\
(4.683)\end{array}$ & $\begin{array}{c}1.841 \\
(6.249)\end{array}$ \\
\hline EXRET-CA & $\begin{array}{c}0.154 \\
(0.065)\end{array}$ & $\begin{array}{l}-1.300 \\
(2.566)\end{array}$ & $\begin{array}{c}0.896 \\
(0.990)\end{array}$ & $\begin{array}{c}2.766 \\
(3.320)\end{array}$ & $\begin{array}{c}4.156 \\
(4.768)\end{array}$ & $\begin{array}{c}4.359 \\
(5.362)\end{array}$ \\
\hline EXRET-IT & $\begin{array}{c}0.117 \\
(0.090)\end{array}$ & $\begin{array}{l}-6.359 \\
(3.498)\end{array}$ & $\begin{array}{c}0.370 \\
(1.248)\end{array}$ & $\begin{array}{c}2.810 \\
(3.700)\end{array}$ & $\begin{array}{c}8.547 \\
(4.635)\end{array}$ & $\begin{array}{l}-3.093 \\
(6.885)\end{array}$ \\
\hline \multicolumn{7}{|c|}{ Panel C: Constrained Prices of Risks and Estimate of ( } \\
\hline $\begin{array}{c}\text { Prices of } \\
\text { Risks }\end{array}$ & $\begin{array}{c}4.065 \\
(1.541)\end{array}$ & $\begin{array}{c}-0.308 \\
(1.187)\end{array}$ & $\begin{array}{c}0.689 \\
(0.809) \\
\end{array}$ & $\begin{array}{c}0.370 \\
(0.550)\end{array}$ & $\begin{array}{c}2.411 \\
(1.834)\end{array}$ & \\
\hline( & $\begin{array}{c}5.058 \\
(2.539)\end{array}$ & & $\begin{array}{c}P^{2}(6) \\
p \text {-value }\end{array}$ & $\begin{array}{l}1.234 \\
0.975\end{array}$ & & \\
\hline
\end{tabular}


Note to Table 6: This table contains the 73 constrained parameter estimates from the dynamic pricing model. Panel A reports the forecasting equations from the VAR. Panel B reports the forecasting equations from the $\mathrm{G} 7$ excess equity returns. Panel $\mathrm{C}$ reports the constrained prices of risks, the estimate of the coefficient of relative risk aversion, (, and the test of the model's six overidentifying conditions. The forecasting variables are the real return on the MSCI world market portfolio (RRET), the logarithm of dividends relative to earnings (LOGDE), the logarithm of the dividend-price ratio (LOGDP), the onemonth Treasury bill interest rate minus its twelve-month moving average (RREL), and the 30-year minus one-year Treasury bond term spread (TSPD). The assets are the excess dollar equity returns on the G7 countries. The sample period is 1970:01 to 1998:04. 
Table 7: GMM Estimates Jointly With Unconstrained Risk Prices

\begin{tabular}{|c|c|c|c|c|c|c|}
\hline \multirow[b]{2}{*}{$\begin{array}{l}\text { Dependent } \\
\text { Variable }\end{array}$} & \multicolumn{6}{|c|}{ Coefficients on Regressors } \\
\hline & $\begin{array}{l}\text { RRET } \\
\text { (std.err.) }\end{array}$ & $\begin{array}{l}\text { LOGDE } \\
\text { (std.err.) }\end{array}$ & $\begin{array}{l}\text { LOGDP } \\
\text { (std.err.) }\end{array}$ & $\begin{array}{l}\text { RREL } \\
\text { (std.err.) }\end{array}$ & $\begin{array}{c}\text { TSPD } \\
\text { (std.err.) }\end{array}$ & $\begin{array}{l}\text { CONST } \\
\text { (std.err.) }\end{array}$ \\
\hline \multicolumn{7}{|c|}{ Panel A: VAR } \\
\hline RRET & $\begin{array}{c}0.057 \\
(0.063)\end{array}$ & $\begin{array}{l}-3.974 \\
(2.128)\end{array}$ & $\begin{array}{c}1.097 \\
(0.744)\end{array}$ & $\begin{array}{c}0.900 \\
(2.177)\end{array}$ & $\begin{array}{c}9.546 \\
(3.044)\end{array}$ & $\begin{array}{c}3.275 \\
(4.198)\end{array}$ \\
\hline LOGDE & $\begin{array}{r}-0.0001 \\
(0.0003)\end{array}$ & $\begin{array}{c}0.963 \\
(0.017)\end{array}$ & $\begin{array}{c}0.005 \\
(0.004)\end{array}$ & $\begin{array}{c}-0.038 \\
(0.015)\end{array}$ & $\begin{array}{c}0.012 \\
(0.019)\end{array}$ & $\begin{array}{l}-0.001 \\
(0.022)\end{array}$ \\
\hline LOGDP & $\begin{array}{l}-0.001 \\
(0.001)\end{array}$ & $\begin{array}{c}0.015 \\
(0.022)\end{array}$ & $\begin{array}{c}0.986 \\
(0.008)\end{array}$ & $\begin{array}{l}-0.001 \\
(0.021)\end{array}$ & $\begin{array}{l}-0.081 \\
(0.030)\end{array}$ & $\begin{array}{l}-0.069 \\
(0.044)\end{array}$ \\
\hline RREL & $\begin{array}{l}-0.002 \\
(0.001)\end{array}$ & $\begin{array}{c}0.113 \\
(0.039)\end{array}$ & $\begin{array}{l}-0.057 \\
(0.016)\end{array}$ & $\begin{array}{c}0.575 \\
(0.059)\end{array}$ & $\begin{array}{l}-0.359 \\
(0.068)\end{array}$ & $\begin{array}{l}-0.224 \\
(0.082)\end{array}$ \\
\hline TSPD & $\begin{array}{l}-0.001 \\
(0.001)\end{array}$ & $\begin{array}{c}0.017 \\
(0.017)\end{array}$ & $\begin{array}{c}0.001 \\
(0.007)\end{array}$ & $\begin{array}{c}0.017 \\
(0.031)\end{array}$ & $\begin{array}{c}0.951 \\
(0.029)\end{array}$ & $\begin{array}{c}0.023 \\
(0.036)\end{array}$ \\
\hline \multicolumn{7}{|c|}{ Panel B: Forecasting equations } \\
\hline EXRET-US & $\begin{array}{c}0.004 \\
(0.072)\end{array}$ & $\begin{array}{l}-4.427 \\
(2.247)\end{array}$ & $\begin{array}{c}0.570 \\
(0.846)\end{array}$ & $\begin{array}{l}-0.588 \\
(2.572)\end{array}$ & $\begin{array}{c}7.292 \\
(3.423)\end{array}$ & $\begin{array}{l}-0.045 \\
(4.664)\end{array}$ \\
\hline EXRET-JP & $\begin{array}{c}0.184 \\
(0.106)\end{array}$ & $\begin{array}{c}1.527 \\
(3.310)\end{array}$ & $\begin{array}{c}2.628 \\
(1.067)\end{array}$ & $\begin{array}{c}2.543 \\
(3.391)\end{array}$ & $\begin{array}{l}10.159 \\
(4.064)\end{array}$ & $\begin{array}{l}16.284 \\
(6.177)\end{array}$ \\
\hline EXRET-GE & $\begin{array}{c}0.026 \\
(0.099)\end{array}$ & $\begin{array}{l}-5.351 \\
(2.892)\end{array}$ & $\begin{array}{c}0.684 \\
(0.979)\end{array}$ & $\begin{array}{l}-0.289 \\
(2.984)\end{array}$ & $\begin{array}{c}9.644 \\
(4.029)\end{array}$ & $\begin{array}{l}-0.285 \\
(5.767)\end{array}$ \\
\hline EXRET-UK & $\begin{array}{c}0.033 \\
(0.100)\end{array}$ & $\begin{array}{l}-7.256 \\
(3.967)\end{array}$ & $\begin{array}{c}1.919 \\
(1.505)\end{array}$ & $\begin{array}{c}1.234 \\
(3.352)\end{array}$ & $\begin{array}{l}13.842 \\
(5.671)\end{array}$ & $\begin{array}{c}5.326 \\
(7.274)\end{array}$ \\
\hline EXRET-FR & $\begin{array}{c}0.019 \\
(0.088)\end{array}$ & $\begin{array}{l}-5.058 \\
(3.092)\end{array}$ & $\begin{array}{c}1.001 \\
(1.215)\end{array}$ & $\begin{array}{c}1.390 \\
(3.515)\end{array}$ & $\begin{array}{l}11.285 \\
(4.803)\end{array}$ & $\begin{array}{c}1.682 \\
(6.610)\end{array}$ \\
\hline EXRET-CA & $\begin{array}{c}0.151 \\
(0.066)\end{array}$ & $\begin{array}{l}-1.567 \\
(2.649)\end{array}$ & $\begin{array}{c}0.762 \\
(1.019)\end{array}$ & $\begin{array}{c}2.994 \\
(3.311)\end{array}$ & $\begin{array}{c}5.096 \\
(4.901)\end{array}$ & $\begin{array}{c}3.164 \\
(5.584)\end{array}$ \\
\hline EXRET-IT & $\begin{array}{c}0.111 \\
(0.091)\end{array}$ & $\begin{array}{l}-6.765 \\
(3.554)\end{array}$ & $\begin{array}{c}0.249 \\
(1.288)\end{array}$ & $\begin{array}{c}2.326 \\
(3.799)\end{array}$ & $\begin{array}{c}8.787 \\
(4.691)\end{array}$ & $\begin{array}{l}-4.303 \\
(7.158)\end{array}$ \\
\hline \multicolumn{7}{|c|}{ Panel C: Unconstrained Prices of Risks } \\
\hline \multirow[t]{2}{*}{ Prices of Risks } & $\begin{array}{c}3.589 \\
(2.948)\end{array}$ & $\begin{array}{c}-1.751 \\
(19.247)\end{array}$ & $\begin{array}{c}-13.337 \\
(39.381)\end{array}$ & $\begin{array}{c}18.714 \\
(46.744)\end{array}$ & $\begin{array}{c}22.946 \\
(66.272)\end{array}$ & \\
\hline & & & $\begin{array}{c}\mathrm{P}^{2}(2) \\
\mathrm{p} \text {-value }\end{array}$ & $\begin{array}{l}0.133 \\
0.975 \\
\end{array}$ & & \\
\hline
\end{tabular}


Notes to Table 7: This table contains the 77 parameter estimates from the APT version of the dynamic pricing model. Panel A reports the forecasting equations from the VAR. Panel B reports the forecasting equations from the $\mathrm{G} 7$ excess returns. Panel $\mathrm{C}$ reports the unconstrained prices of risks and the test of the model's two overidentifying conditions. The forecasting variables are the real return on the MSCI world market portfolio (RRET), the logarithm of dividends relative to earnings (LOGDE), the logarithm of the dividend-price ratio (LOGDP), the one-month Treasury bill interest rate minus its twelve-month moving average (RREL), and the 30-year minus one-year Treasury bond term spread (TSPD). The assets are the excess dollar equity returns on the G7 countries. The sample period is 1970:01 to 1998:04. 
Table 8: Pricing Components and Errors from the Dynamic Asset Pricing Model

This table reports the average adjusted percentage monthly excess rates of return, defined in equation (19), for the seven countries for two samples. The first is our base sample of 1970:01 to 1998:04, and the second is a sub-sample from 1975:01 to 1995:12, which is used by Fama and French (1998). The pricing model predicts that the average adjusted return contains two parts: a part corresponding to covariance with the market portfolio, $\left(\mathrm{V}_{\mathrm{i}, \mathrm{m}}\right.$, and a part corresponding to covariance with the innovation in discounted expected future returns, $\left((-1) \mathrm{V}_{\mathrm{i}, \mathrm{h}}\right.$. The pricing error is the difference between the data and the model's prediction.

\begin{tabular}{ccccc}
\hline \hline \multicolumn{5}{c}{ Sample: $1970: 01-1998: 04$} \\
$\left(\mathrm{~V}_{\mathrm{i}, \mathrm{m}}\right.$ & $\left((-1) \mathrm{V}_{\mathrm{i}, \mathrm{h}}\right.$ & Pricing Error \\
\hline EXRET-US & Ave. Adj. & 0.724 & -0.184 & 0.005 \\
EXRET-JP & 0.545 & 0.866 & -0.132 & -0.005 \\
EXRET-GE & 0.730 & 0.661 & -0.076 & 0.002 \\
EXRET-UK & 0.587 & 0.936 & -0.181 & 0.002 \\
EXRET-FR & 0.757 & 0.839 & -0.152 & -0.001 \\
EXRET-CA & 0.686 & 0.771 & -0.171 & -0.019 \\
EXRET-IT & 0.582 & 0.661 & -0.133 & -0.014 \\
\hline
\end{tabular}

\begin{tabular}{ccccc}
\hline \multicolumn{5}{c}{ Sample: $1975: 01-1995: 12$} \\
\hline EXRET-US & Ave. Adj. & $\left(\mathrm{V}_{\mathrm{i}, \mathrm{m}}\right.$ & $\left((-1) \mathrm{V}_{\mathrm{i}, \mathrm{h}}\right.$ & Pricing Error \\
\hline EXRET-JP & 0.569 & 0.795 & -0.226 & 0.001 \\
EXRET-GE & 0.930 & 1.146 & -0.202 & -0.014 \\
EXRET-UK & 0.679 & 0.805 & -0.115 & -0.011 \\
EXRET-FR & 0.828 & 1.066 & -0.231 & -0.007 \\
EXRET-CA & 0.797 & 1.012 & -0.197 & -0.018 \\
EXRET-IT & 0.599 & 0.877 & -0.233 & -0.045 \\
\hline
\end{tabular}




\section{Table 9: Estimation, Pricing Components and Pricing Errors from the Static CAPM}

This table contains the parameter estimates from the static CAPM pricing model. Panel A reports the parameters from equation (20) and the test of the model's six overidentifying conditions. Panel B reports the average adjusted percentage monthly excess rates of return, defined in equation (19), for the seven countries for two samples. The first is our base sample of 1970:01 to 1998:04, and the second is a subsample from 1975:01 to 1995:12, which is used by Fama and French (1998). The pricing model predicts that the average adjusted return is explained by covariance of a return with the return on market portfolio, $\left(\mathrm{V}_{\mathrm{i}, \mathrm{m}}\right.$. The pricing error is the difference between the data and the model's prediction.

\begin{tabular}{ccc}
\hline \hline & \multicolumn{3}{c}{ Panel A: Parameter Estimates } \\
\hline & Sample: 1970:01-1998:04 & Sample: 1975:1-1995:12 \\
& Coefficient & Coefficient \\
(std. Err.) & (std. err.) \\
\hline RRET & 0.554 & 0.761 \\
& $(0.225)$ & $(0.259)$ \\
EXRET-US & 0.473 & 0.583 \\
& $(0.199)$ & $(0.212)$ \\
EXRET-JP & 0.471 & 0.744 \\
& $(0.249)$ & $(0.321)$ \\
EXRET-GE & 0.350 & 0.500 \\
& $(0.180)$ & $(0.215)$ \\
EXRET-UK & 0.504 & 0.723 \\
& $(0.267)$ & $(0.325)$ \\
EXRET-FR & 0.437 & 0.627 \\
& $(0.237)$ & $(0.290)$ \\
EXRET-CA & 0.443 & 0.566 \\
& $(0.207)$ & $(0.233)$ \\
EXRET-IT & 0.227 & 0.399 \\
& $(0.189)$ & $(0.212)$ \\
\hline ( & 3.776 & 5.001 \\
(std.err.) & $(1.478)$ & $(1.757)$ \\
\hline P-(6) & 1.080 & 2.712 \\
p-value & 0.982 & 0.844 \\
\hline
\end{tabular}

Panel B: Pricing Components and Errors

\begin{tabular}{ccccccc}
\hline & \multicolumn{3}{c}{ Sample: 1970:01-1998:04 } & \multicolumn{2}{c}{ Sample: 1975:1-1995:12 } \\
\hline & Ave. Adj. & $\left(\mathrm{V}_{\mathrm{i}, \mathrm{m}}\right.$ & $\begin{array}{c}\text { Pricing } \\
\text { Error }\end{array}$ & Ave. Adj. & $\left(\mathrm{V}_{\mathrm{i}, \mathrm{m}}\right.$ & $\begin{array}{c}\text { Pricing } \\
\text { Error }\end{array}$ \\
\hline EXRET-US & 0.568 & 0.568 & -0.0001 & 0.673 & 0.694 & -0.021 \\
EXRET-JP & 0.683 & 0.682 & 0.001 & 0.962 & 0.978 & -0.015 \\
EXRET-GE & 0.521 & 0.522 & -0.001 & 0.682 & 0.712 & -0.030 \\
EXRET-UK & 0.737 & 0.739 & -0.002 & 0.971 & 1.007 & -0.036 \\
EXRET-FR & 0.663 & 0.664 & -0.001 & 0.870 & 0.903 & -0.033 \\
EXRET-CA & 0.586 & 0.591 & -0.005 & 0.717 & 0.761 & -0.044 \\
EXRET-IT & 0.513 & 0.519 & -0.006 & 0.695 & 0.730 & -0.035 \\
\hline
\end{tabular}




\section{Table 10: Pricing Components and Errors from the Static CAPM Fama-French (1997) High Book-to-Market Portfolios \\ Sample: 1975:01-1995:12}

This table investigates the ability of the static CAPM to price assets with high book-to-market ratios. It reports the average adjusted percentage monthly excess rates of return for these assets, defined in equation (19), for six countries. The sample is 1975:01 to 1995:12, which is used by Fama and French (1998). The pricing model predicts that the average adjusted return is explained by covariance of a return with the return on market portfolio, $\left(\mathrm{V}_{\mathrm{i}, \mathrm{m}}\right.$. The pricing error is the difference between the data and the model's prediction.

\begin{tabular}{cccc}
\hline \hline & Ave. Adj. & $\left(\mathrm{V}_{\mathrm{i}, \mathrm{m}}\right.$ & $\begin{array}{c}\text { Pricing } \\
\text { Error }\end{array}$ \\
\hline EXRET-US & 0.946 & 0.644 & 0.301 \\
EXRET-JP & 1.207 & 0.890 & 0.317 \\
EXRET-GE & 0.895 & 0.680 & 0.215 \\
EXRET-UK & 1.340 & 1.024 & 0.317 \\
EXRET-FR & 1.181 & 0.893 & 0.287 \\
EXRET-IT & 0.373 & 0.705 & -0.331 \\
\hline
\end{tabular}

\section{Table 11: Pricing Components and Errors from the Dynamic Asset Pricing Model Fama-French (1997) High Book-to-Market Portfolios Sample: 1975:01-1995:12}

This table investigates the ability of the dynamic asset pricing model to price assets with high book-tomarket ratios. It reports the average adjusted percentage monthly excess rates of return for these assets, defined in equation (19), for six countries. The sample is 1975:01 to 1995:12, which is used by Fama and French (1998). The pricing model predicts that the average adjusted return contains two parts: a part corresponding to covariance with the market portfolio, $\left(\mathrm{V}_{\mathrm{i}, \mathrm{m}}\right.$, and a part corresponding to covariance with the innovation in discounted expected future returns, $\left((-1) \mathrm{V}_{\mathrm{i}, \mathrm{h}}\right.$. The pricing error is the difference between the data and the model's prediction.

\begin{tabular}{ccccc}
\hline \hline & Ave. Adj. & $\left(\mathrm{V}_{\mathrm{i}, \mathrm{m}}\right.$ & $\left((-1) \mathrm{V}_{\mathrm{i}, \mathrm{h}}\right.$ & $\begin{array}{c}\text { Pricing } \\
\text { Error }\end{array}$ \\
\hline EXRET-US & 0.870 & 0.710 & -0.189 & 0.349 \\
EXRET-JP & 1.192 & 1.041 & -0.182 & 0.332 \\
EXRET-GE & 0.840 & 0.761 & -0.095 & 0.174 \\
EXRET-UK & 1.142 & 1.096 & -0.221 & 0.267 \\
EXRET-FR & 1.080 & 0.999 & -0.190 & 0.271 \\
EXRET-IT & 0.336 & 0.795 & -0.135 & -0.324 \\
\hline
\end{tabular}




\section{Endnotes}

${ }^{1}$ Hodrick (1981) and Stulz (1981) extended the Merton (1973) analysis to develop international, intertemporal asset pricing models.

2 The model also incorporates human capital as an additional asset.

3 The Euler equation approach of Hansen and Singleton (1982) provided researchers with econometric tools that allowed tests of models in which expected returns on stocks were allowed to fluctuate, but the approach requires correct specification of a representative agent's utility function and direct observations on the consumption of this agent. Both aspects are problematic. ${ }^{4}$ Campbell (1996) also allows for an additional factor in the asset-pricing model related to human wealth. He argues that the return on the real wealth portfolio is appropriately measured as the value-weighted sum of the return on assets and the return on human wealth. Jagannathan and Wang (1996) also include labor income in their analysis. While there may be an assetpricing role for labor income, in a global economy the variable would have to be some measure of the world's labor income. We have made no attempt to measure such a variable.

5 Chang and Hung (1999) independently develop an international version of Campbell's (1996) model allowing for time-varying conditional second moments.

${ }^{6}$ While it is tempting to substitute $F=1$ in equation (7) and conclude that intertemporal considerations are not important in this case, which would imply that equation (9) is wrong, the correct derivation follows Giovannini and Weil (1989) who note that L'Hopital's rule must be applied because $\theta \rightarrow 4$ as $\sigma \rightarrow 1$.

${ }^{7}$ We thank Owen Lamont for providing the data used in the comparisons to his article in Table 4. 
${ }^{8}$ We thank Kenneth French for providing the data on the HBM portfolios used in this part of our paper. 